\title{
KORRUPTIONEN I DET SVENSKA FOLKSTYRET: VAD SÄGER MEDBORGARNA?
}

\author{
Staffan Andersson, Institutionen för statsvetenskap, Linnéuniversitetet \\ E-post I staffan.andersson@lnu.se
}

Tigran Babajan, Institutionen för statsvetenskap, Linnéuniversitetet E-post I tigran.babajan@lnu.se

Korruption, när ämbetsinnehavare missbrukar förtroende eller makt för privat vinning, är något som i alla tider väckt intresse. Klassiska och inflytelserika tänkare som Machiavelli, Montesquieu och Rousseau intresserade sig för korruptionens orsaker och konsekvenser för samhället. Detta intresse har också bestått i modern tid - vilket märks inte minst genom det stora mediala intresset för korruption. Även inom den samhällsvetenskapliga forskningen är dessa frågor viktiga, men storleken på intresset och dess inriktning har varierat över tid. Under 1950-talet och fram till och med 1980-talet så var intresset framförallt riktat mot utvecklingsländer, och det handlade ofta om att förklara varför korruptionen var utbredd. Korruption i etablerade demokratier med marknadsekonomi, i väst, ansågs däremot som ett litet eller obefintligt problem (Heywood 1997; Heywood 2015). 
Från och med 1990-talet skedde dock en viktig förändring. Uppfattningen om korruption och dess betydelse i västländerna förändrades i samband med att kalla krigets uppdelning i väst och öst upphörde. Man blev mindre benägen att ha överseende med och stödja korrupta regimer i fattiga länder (som nu inte hade samma möjlighet att "hota" med att söka stöd från östblocket). Det blev även vanligare att man ställde krav på dessa länder kring korruption och demokrati. Korruptionsproblem blev också tydliga i västländer med en rad skandaler i stora demokratier såsom USA, Tyskland, Frankrike, Italien och Storbritannien. Journalister och forskare började då i allt större grad uppmärksamma korruptionsproblematiken också i de egna länderna. I denna utveckling var internationella organisationers förändrade inställning till korruption viktig (se t.ex. Krastev 2003; De Sousa m.fl. 2009:1-2; Heywood 2015:1). OECD (2011) antog år 1997 konventionen som förbjöd mutor av offentliga tjänstemän i internationella affärstransaktioner. Världsbanken svängde från att tidigare ha sett korruptionsfrågorna som "oberörbara” till att istället fokusera på korruptionsproblem som ett av de viktigaste hindren för ekonomisk utveckling. Bildandet av organisationen Transparency International hade också en avgörande roll i att skapa uppmärksamhet för korruption samt att lyfta behovet av dess bekämpning på den internationella dagordningen (Marquette 2004:414; Andvig 2005; Wolfowitz 2006; De Sousa m.fl. 2009). Transparency Internationals index (Corruption Perceptions Index, CPI), om hur utbredd korruption uppfattas vara i världens länder, fick väldigt stor uppmärksamhet i media, bland nationella och internationella organisationer samt forskare. Indexet, som innehåller länderdata, underlättade forskningen om korruption. Det blev möjligt att studera hur korruption var relaterad till en rad andra faktorer såsom ekonomisk utveckling, tillväxt och demokrati. ${ }^{1}$

I CPI (och andra liknande mätningar) har Sverige sedan mitten av 1990-talet bedömts ha mycket lite korruption (Transparency International 2014). Intresset för korruption i Sverige var också länge lågt och den officiella svenska hållningen kännetecknades av att frågor om korruption och dess bekämpning inte var särskilt framträdande (Andersson 2012). Antalet kända korruptionsbrott i Sverige har också varit lågt (Hols Salén \& Korsell 2013). Likafullt kan man argumentera för att allmänhetens uppfattningar om den offentliga korruptionen är en viktig indikator på förtroendet för den offentliga makten, även om dessa uppfattningar inte behöver stå i samklang med hur mycket verklig korruption det finns (se t.ex. Andvig 2005; Heywood \& Rose 2014). I denna artikel intresserar vi oss därför för frågan om i vilken grad allmänheten i Sverige uppfattar att det finns inslag av korruption i den svenska demokratin. Särskilt fokus riktar vi här mot om korruption uppfattas variera i omfattning mellan olika nivåer i den offentliga förvaltningen i Sverige, vilka erfarenheter invånarna har av olika typer av korruption, liksom vilken betydelse som just egen erfarenhet av korruption har för hur man uppfattar dess omfattning.

\section{Uppfattningar om korruption - vad kan förväntas?}

Är frågor om korruptionens utbredning eller medborgarnas uppfattningar om korruptionsproblematik överhuvudtaget intressant i ett land som S verige? Vårt svar är föga överraskande ja, men det finns också flera skäl till varför vi hävdar detta. 
Ett skäl är att korruptionen också i Sverige fått allt större uppmärksamhet - inte minst till följd av svenska mediers avslöjanden om oegentligheter och korruption både inom offentlig förvaltning och i näringslivet. ${ }^{2}$ Dessutom har undersökningar av medborgarnas attityder pekat på att det finns en allmän uppfattning om att korruption är ett utbrett problem. Baserat på enkätundersökningen Survey 2009 konstaterar Erlingsson och Linde (2011b:148, 150) att en majoritet av medborgarna uppfattar att korruptionen har ökat under de senaste femton åren. Med utgångspunkt i data från Transparency Internationals Global Corruption Barometer visar författarna även att de flesta svaranden också räknar med att korruptionen kommer att öka i framtiden. Forskning också har visat att dessa uppfattningar om korruption påverkar stödet för det demokratiska systemet, vilket ytterligare förstärker betydelsen av dessa frågor i ett svenskt sammanhang (Linde \& Erlingsson 2013). Till detta kan läggas att undersökningar har pekat ut kontrollsystemen av korruption som svaga (se t.ex. Bergh m.fl. 2013:58-62).

Ytterligare ett skäl till att det finns anledning att intressera sig även för lågkorrupta länders korruption är att komparativa undersökningar med utgångspunkt i länderjämförande data, har flera begränsningar (se t.ex. Heywood \& Rose 2014).

Genom att de med endast en siffra anger korruptionen totalt sett i ett land ger de inte möjlighet att undersöka variationen inom ett land, t.ex. mellan olika sektorer. Dylika mätningar tenderar också att fokusera på mutor, men att inte vara lika bra på att fånga andra former av korruption (såsom nepotism och otillbörliga intressekonflikter som inte inbegriper mutor).

Korruptionsindikatorn blir vid sådana mätningar således endimensionell trots att korruption är ett mångfacetterat fenomen (Johnston 2006, 2014, se också Philp 2015). Ett annat problem är att dessa mätningar i stor utsträckning bygger på experters uppfattningar om korruption snarare än faktisk korruption, det vill säga det finns inga mätningar av den verkliga korruptionens omfattning, snarare olika försök att skatta den på bästa sätt (Andvig 2005; Kurtz \& Shrank 2007 ) .

Slutligen kan man konstatera att även om korruptionen faktiskt är låg i ett samhälle relativt andra kan den ändå utgöra ett viktigt problem (se t.ex. Erlingsson \& Linde 2011a). Vidare om korruptionen tillåts stiga kan det sedan vara betydligt svårare att bekämpa den. Forskning visar att om allt fler människor sedan förväntar sig mer korruption och detta i sin tur påverkar deras egna överväganden och benägenhet att delta i korruption kan effekten bli att den också faktiskt ökar (se t.ex. Andvig \& Moene 1990). Det bästa skyddet är därmed att se till att korruption inte får etablera sig och bli en förväntad del av samhällsekonomin.

Från en svensk utgångspunkt kan vi konstatera att den typ av jämförande länderdata som ofta refereras till säger ganska lite om hur korruptionen varierar inom offentlig sektor i Sverige och vilka former den tar sig. Genom att korruption är något som de inblandade i regel vill dölja är den av naturliga skäl svår att mäta (Teorell 2010; Heywood \& Rose 2014). Vi behöver därför en kombination av olika typer av mätningar för att få en mer fullödig bild.

Men vad kan vi då förvänta oss när det gäller hur vanlig korruption är i olika sektorer i samhället och vilka former av korruption som är framträdande i Sverige? Vi har ovan kort diskuterat att man i jämförande forskning bedömer korruptionen som låg i Sverige. 
Man bör dock beakta, särskilt mot bakgrund av hur korruption kan variera inom ett land och vilka former den tar sig, att forskningen visat hur omfattningen av korruption och samhällsstyrningens kvalitet inom ett land kan variera mellan olika regioner (Charron m.fl. 2011; Charron m.fl. 2013; Alam 1995), att korruptionen kan variera mellan olika sektorer och nivåer av förvaltningen i ett och samma land (Alam 1995), liksom att dess former kan förväntas variera mellan och inom länder beroende på hur de politiska och ekonomiska förutsättningarna ter sig och hur politiskt deltagande förhåller sig till samhällets institutioner (Heidenheimer 1989; Johnston 2005, 2014). Korruptionssyndromen i ett samhälle återspeglar därmed hur politisk och ekonomisk makt eftersträvas, används och hur statliga, sociala och politiska strukturer främjar eller begränsar dessa aktiviteter. I den typ av samhälle som Sverige representerar, ett demokratiskt system med politisk konkurrens och väl fungerande institutioner och utvecklad marknadsekonomi, förväntas korruption mycket att handla om att inom ramen för befintliga offentliga institutioner vinna korrupt inflytande, där politiker ofta erbjuder sina kontakter i utbyte mot tillåtna eller otillåtna motprestationer (Johnston 2005:39-42). Fokus vad gäller korruptionsfrågor har sedan 1990-talet framförallt legat på mutor, men i den typ av korruptionssyndrom som kan förväntas i ett land som Sverige är mutor bara toppen av ett isberg, det vill säga andra former av korruption kan förväntas vara framträdande (Johnston 2005). Inte minst kan det handla om olika typer av intressekonflikter som påverkar beslutsfattande (se Andersson \& Anechiarico 2015).

\section{Uppfattningar om korruption i det offentliga Sverige}

För de empiriska analyserna i denna artikel använder vi data från den riksrepresentativa enkätundersökningen Survey 2012 (Hagevi 2014) för att se vilka bedömningar medborgarna gör i ett antal frågor. Det gäller först vilka erfarenheter respondenterna har kring olika typer av korruption, därefter hur vanlig korruption i den offentliga förvaltningens olika nivåer bedöms vara och slutligen hur respondenternas erfarenheter av olika korruptionstyper relaterar till bedömningar av korruptionens omfattning i den offentliga förvaltningens olika nivåer.

Tidigare studier har visat att svenskar uppfattar korruption som vanligt förekommande trots Sveriges fördelaktiga position i ett komparativt perspektiv: väldigt få tror att politiker och tjänstemän inte alls är involverade i korruption (drygt 11 respektive 8 procent) (Linde \& Erlingsson 2013:591-592; se också Bauhr \& Oscarsson 2011:86-87).

Liknande siffror framkom i en rapport från Europeiska kommissionen (2014:6) där 44 procent av svenska respondenter uppfattade korruptionen som utbredd. Det är också en utbredd uppfattning att personliga kontakter spelar stor roll för hur förvaltningsärenden hanteras (Linde \& Erlingsson 2013:590-591). Det är ett viktigt resultat med tanke på hur detta fångar upp situationer som kan handla om korruption, liksom att opartiskhet är en förutsättning för en god förvaltning (Rothstein \& Teorell 2008). Dock står ovanstående uppfattningar om korruption som relativt vanlig i kontrast till vad de komparativa studierna som refererats ovan kommit fram till. 
Resultaten skiljer sig också från resultat baserade på frågor om allmänhetens egna erfarenheter av mutor i kontakter med offentlig förvaltning i SOM-undersökningarna, European Social Survey, Global Corruption Barometer och Europeiska kommissionens anti-korruptionsrapport, som ligger runt en procent (Oscarsson 2010; Bergh m.fl. 2013:84; Transparency International 2006, 2007; European Commission 2014:6). Dessa skillnader indikerar att vi kan förvänta oss att korruption bedöms som lägre när respondenterna enbart svarar utifrån egna upplevelser; frågan blir också bredare när den handlar om korruption, och fler handlingar därmed inkluderas, än då den enbart handlar om mutor.

De frågor från Survey 2012 som vi använder gör det möjligt att beakta både effekten av att fråga om respondenternas egna erfarenheter eller deras uppfattningar baserat på annat än egen erfarenhet och hur uppfattningar om förekomsten av korruption relaterar till vilka erfarenheter man har av korruption inom den offentliga förvaltningen. Vi vänder oss först mot frågan om vilka erfarenheter allmänheten har av olika typer av korruption (figur 1).

För ändamålet använder vi en fråga om otillbörligt gynnande i offentlig sektor. Respondenterna fick ta ställning till om man kände till situationer, exemplifierat av fyra olika situationer eller scenarier $^{3}$, där politiker eller tjänstemän i offentlig sektor, eller annan som varit i kontakt med offentlig sektor, blivit eller försökt bli gynnad: att någon i eller i kontakt med offentlig sektor har blivit erbjuden eller har uppmanats att erbjuda pengar ("Pengar”); fått eller har blivit erbjuden jobb i offentlig sektor på grund av släktskap eller vänskap (”Vänskap ger jobb”); någon i eller i kontakt med offentlig sektor har blivit uppmanad att ge eller att ta emot dyra presenter eller varor ("Presenter”); och slutligen, någon i eller i kontakt med offentlig sektor har uppmanats att bjuda på eller har fått ett erbjudande om en dyr resa som gåva ("Resa").

I svaren ombads respondenterna att uppge i vilken grad man hade erfarenhet av de olika situationerna utifrån en skala som gick från att de själva varit med om den situation som beskrivits till att bara ha hört talas om den, närmare bestämt: 1) om man inte alls varit med om eller hört talas om den beskrivna situationen; 2) om man själv har varit med om den beskrivna situationen ${ }^{4}$; 3) om man känner någon som varit med om situationen; eller 4) om man bara har hört talas om den beskrivna situationen, men inte känner någon som varit med om den. Frågan är således brett hållen och omfattar både mutliknande (Pengar, Presenter, Resa) och nepotismliknande (Vänskap ger jobb) situationer. 
Figur 1. Erfarenhet av olika korruptionssituationer inom offentlig sektor

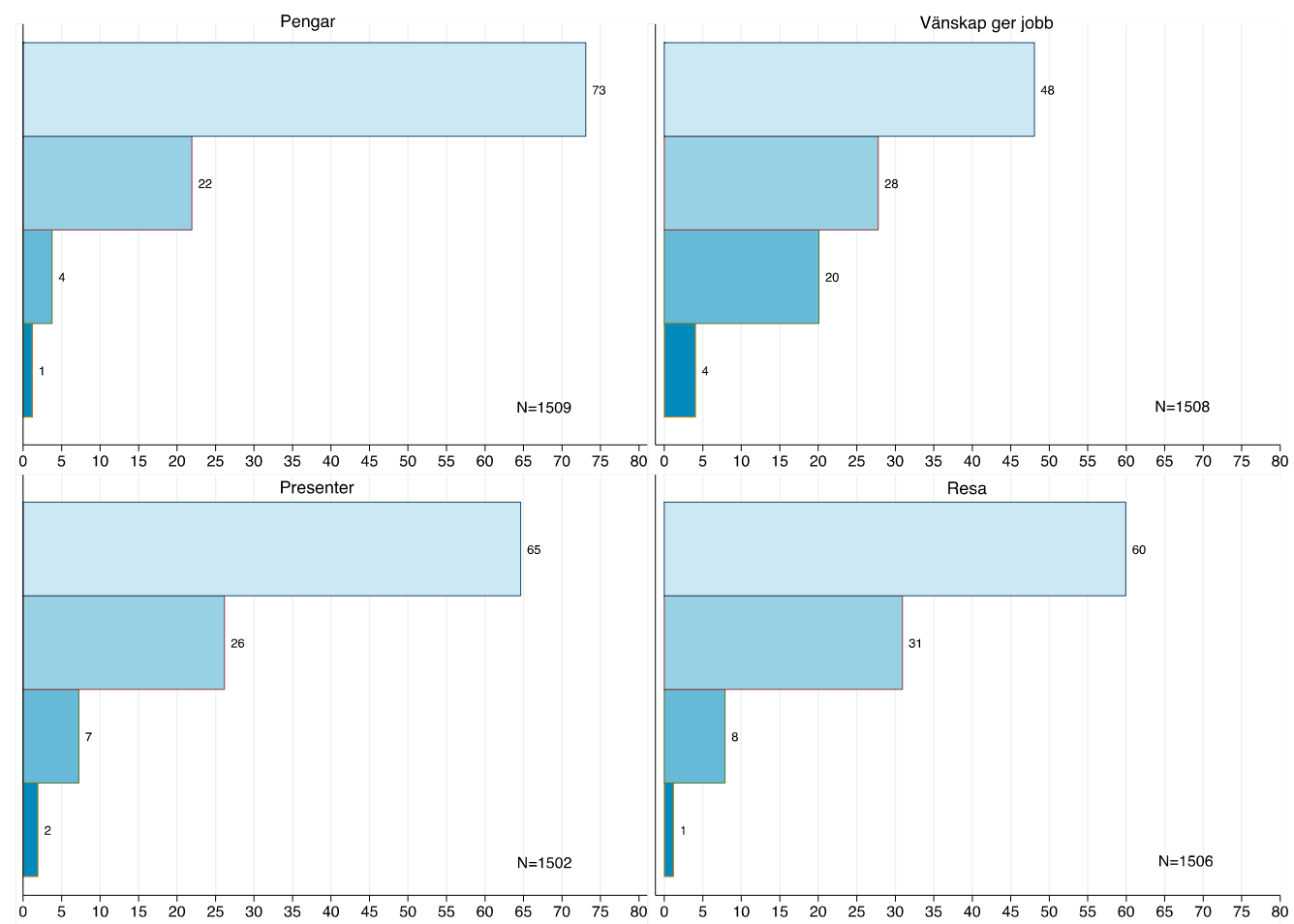

Nej

$\mathrm{Ja}$, jag har hört talas om det, men känner ingen som varit med om detta

$\mathrm{Ja}$, jag kănner nágon som varit med om detta

Ja, jaq har siälv varit med om detta

Kommentar: Frågan och de fullständiga beskrivningarna av situationerna löd: Känner du till att någon politiker eller tjänsteman i offentlig sektor (kommun, landsting, stat), eller någon som varit i kontakt med offentlig sektor, har blivit eller har försökt att bli gynnad genom följande exempel? A) Någon i eller i kontakt med offentlig sektor ( $\mathrm{t}$ ex. skola, sjukhus, kommun, myndighet) har blivit erbjuden eller har uppmanats att erbjuda pengar ("Pengar”), B) Fått eller har blivit erbjuden jobb i offentlig sektor på grund av släktskap eller vänskap ("Vänskap ger jobb”), C) Någon i eller i kontakt med offentlig sektor har blivit uppmanad att ge eller att ta emot dyra presenter eller varor ("Presenter"), D) Någon i eller i kontakt med offentlig sektor har uppmanats att bjuda på eller har fått ett erbjudande om en dyr resa som gåva ("Resa”). N-talet anger antal svarande.

Resultatet är att för de mutliknande situationerna svarar en stor majoritet ”Nej”, alltså att man inte känner till detta (Pengar: 73 \%, Presenter: 65 \%, Resa: 60 \%), men däremot är det en knapp minoritet som svarar "Nej” när det gäller det nepotismliknande scenariot (Vänskap ger jobb: 48 \%). Således framträder en skillnad där fler respondenter har någon form av erfarenhet eller kännedom om nepotismsituationen jämfört med mutsituationerna. 
Det som skiljer mutsituationerna från nepotism är framförallt att det är fler respondenter som hävdar att de har någon form av egen erfarenhet av det senare, antingen genom att man själv varit med om det eller känner någon som varit det. Det är 4 procent som uppger att de själva varit med om nepotismsituationen Vänskap ger jobb, jämfört med 1 procent för de mutliknande situationerna Pengar och Resa, och 2 procent för Presenter. Skillnaderna mellan mutsituationerna och nepotismsituationen blir större när vi utvidgar jämförelsen till de som känner någon som varit med om situationen: 20 procent för nepotismsituationen (Vänskap ger jobb) jämfört med, för mutsituationerna, 4 procent för Pengar, 7 procent för Presenter och 8 procent för Resa.

Vidgar vi ytterligare till att beakta de som hört talas om situationen (men utan att varken ha erfarit den själva eller känna någon som erfarit den) blir följaktligen antalet högre. En skillnad som framträder mot när vi jämförde de andra kategorierna är att ungefär lika många uppger att de hört talas om situationen Resa (31 \%) som Vänskap ger jobb (28 \%). Här är en tänkbar förklaring till det höga resultatet för Resa att den typen av situation har varit föremål för avslöjanden och rapportering i media. En intressant iakttagelse utifrån figur 1 vad beträffar respondenternas erfarenhet av och kännedom om olika korruptionstyper är att det högre resultatet för den nepotismliknande situationen är i linje med vad vi kunde förvänta oss utifrån Johnstons resonemang (se ovan) om mutor kontra andra korruptionsformer. Det är också så att korruptionsbilden förändras när vi går från att basera den på egna erfarenheter till att inkludera vad man hört från andra.

Ju mer den enbart baseras på egna självupplevda erfarenheter (varierar mellan lägst 1 och högst 4 procent som själva har erfarit situationerna), desto lägre blir korruption medan när den också tar in vad man hört från andra eller i media så blir uppfattningen att den är mer utbredd, vilket ju också är i linje med vad vi kunde förvänta.

Vi ska nu gå vidare med att relatera dessa resultat för de olika typerna av korruption till hur man uppfattar korruptionen på olika nivåer i den svenska offentliga förvaltningen. För att kunna göra det ska vi först se hur vanligt allmänheten uppfattar att korruption är på olika förvaltningsnivåer, där vi redovisar resultaten för kommuner, landsting, Migrationsverket, Polisen och EU (tabell 1). Eftersom tidigare studier har pekat på den kommunala nivån som särskilt riskbenägen (se t.ex. Bergh m.fl. 2013; Wångmar 2013; Statskontoret 2012; Andersson \& Erlingsson 2010; Erlingsson m.fl. 2008; Erlingsson 2006; Andersson 2002), likaså att kommunala oegentligheter fått stor uppmärksamhet i media så finns en förväntan att allmänhetens bedömning följer samma mönster även i Survey 2012. 
Tabell 1. Uppfattning om hur vanligt det är med korruption i offentlig förvaltning.

\begin{tabular}{l|l|l|l|l|l|l}
\hline & $\begin{array}{l}\text { Mycket } \\
\text { eller } \\
\text { ganska } \\
\text { vanligt }\end{array}$ & $\begin{array}{l}\text { Varken } \\
\text { vanligt } \\
\text { eller } \\
\text { ovanligt }\end{array}$ & $\begin{array}{l}\text { Ganska } \\
\text { eller } \\
\text { mycket } \\
\text { ovanligt }\end{array}$ & $\begin{array}{l}\text { Summa } \\
\text { procent }\end{array}$ & $\begin{array}{l}\text { Antal } \\
\text { svarande }\end{array}$ & Balansmått \\
\hline Kommuner & 62 & 27 & 11 & 100 & 1508 & 51 \\
Landsting & 52 & 32 & 16 & 100 & 1503 & 36 \\
Migrationsverket & 38 & 36 & 26 & 100 & 1498 & 12 \\
Polisen & 38 & 33 & 29 & 100 & 1503 & 9 \\
EU & 62 & 25 & 13 & 100 & 1502 & 49 \\
\hline
\end{tabular}

Kommentar: Frågan här löd: Allmänt sett, hur vanligt tror du det är med korruption som mutor, vänskapskorruption, svågerpolitik och liknande i följande typer av institutioner och organisationer? Balansmåttet är beräknat som skillnaden mellan den andel som svarar mycket vanligt eller ganska vanligt och den andel som svarar ganska ovanligt eller mycket ovanligt.

Av tabell 1 framgår att korruption på statlig nivå, bedömt utifrån myndigheterna Migrationsverket och Polisen, uppfattas som betydligt mindre vanligt än på de andra nivåerna som ligger under och över centralmakten i folkstyret, det vill säga kommuner och landsting respektive EU. Balansmåttet (skillnaden mellan de som svarar mycket eller ganska vanligt och de som svarar ganska eller mycket ovanligt) visar att korruptionen i fallande ordning uppfattas vara vanligast i kommunerna, EU, landstingen, Migrationsverket och Polisen. ${ }^{5}$ Nästan två tredjedelar av respondenterna anser att korruption är ganska eller mycket vanlig i svenska kommuner respektive EU (62\%) medan motsvarande siffror för landstinget är 52 procent och Polisen och Migrationsverket 38 procent. ${ }^{6}$ Övergripande kan vi konstatera att respondenterna uppfattar korruption som vanligare på kommunal nivå jämfört med statlig, i linje med vad vi kunde förvänta utifrån tidigare studier. ${ }^{7}$ Polisen och Migrationsverket kan också betraktas som en rimlig och relevant indikator på medborgarnas uppfattning om korruption i den statliga sektorn: i dessa respektive verksamheter finns många riskfaktorer för korruption (t.ex. positiva eller negativa myndighetsbeslut mot den enskilde) och flera korruptionsfall har uppmärksammats inom Migrationsverket i medier (Sydsvenskan 2013-06-25, Svenska Dagbladet 2013-03-25), vilket torde göra risken låg för att vi med dessa myndigheter underskattar människors uppfattning om korruption i statliga myndigheter. ${ }^{8}$

Utifrån detta övergår vi slutligen till att studera hur erfarenheterna av olika typer av korruption som respondenterna har (redovisade i figur 1) relaterar till deras bedömningar av korruption i den offentliga förvaltningen (redovisade i tabell 1). Vi gör detta genom att först redovisa resultaten för den nepotismliknande situationen (Vänskap ger jobb) och sedan har vi av presentationsskäl valt ut en av de mutliknande situationerna (Presenter). ${ }^{9}$ EU-nivån redovisas inte eftersom det är relativt få personer som har erfarenhet av kontakter med EU-institutioner jämfört med statliga och kommunala myndigheter. 
I figur 2 har vi sammanställt respondenternas erfarenheter och kännedom om situationer där någon har fått eller har blivit erbjuden jobb i offentlig sektor på grund av släktskap eller vänskap. Liksom figur 1 är figur 2 utformad så att ju mörkare staplar desto mer bygger svaret på egen erfarenhet. Vidare är varje delfigur uppdelad på två kategorier: de respondenter som ser korruption som (ganska eller mycket) ovanligt respektive (ganska eller mycket) vanligt. ${ }^{10}$

Studerar vi resultaten närmare kan vi för kommuner konstatera att av de respondenter som anser att korruptionen är vanlig (de som svarat ganska eller mycket vanligt) $\mathrm{i}$ kommuner är det ungefär 28 procent av dem som själva varit med om eller känner någon som varit med om situationen. Motsvarande siffra för de som uppfattar korruptionen som ovanlig (de som svarat ganska eller mycket ovanligt) i kommunerna är 17 procent. Vad gäller landstingen är bilden nästan likadan: 30 procent mot 18. När det gäller de två statliga myndigheterna Migrationsverket och Polisen - är resultaten dem emellan nästan identiska. För det första har 27 respektive 28 procent av respondenterna, som uppfattar att korruptionen är vanligt förekommande inom Migrationsverket respektive Polisen, själva varit med om eller känner någon som varit med om situationen (Vänskap ger jobb). Vad gäller de respondenter som uppgett att korruption i allmänhet är ovanlig kan vi konstatera att 23 procent (Migrationsverket) respektive 22 procent (Polisen) talar om att de själva varit med om eller känner någon som varit med om situationen.

\section{Figur 2. Samband mellan erfarenhet av situationen "Vänskap ger jobb” och bedömning av korruption i offentlig förvaltning}

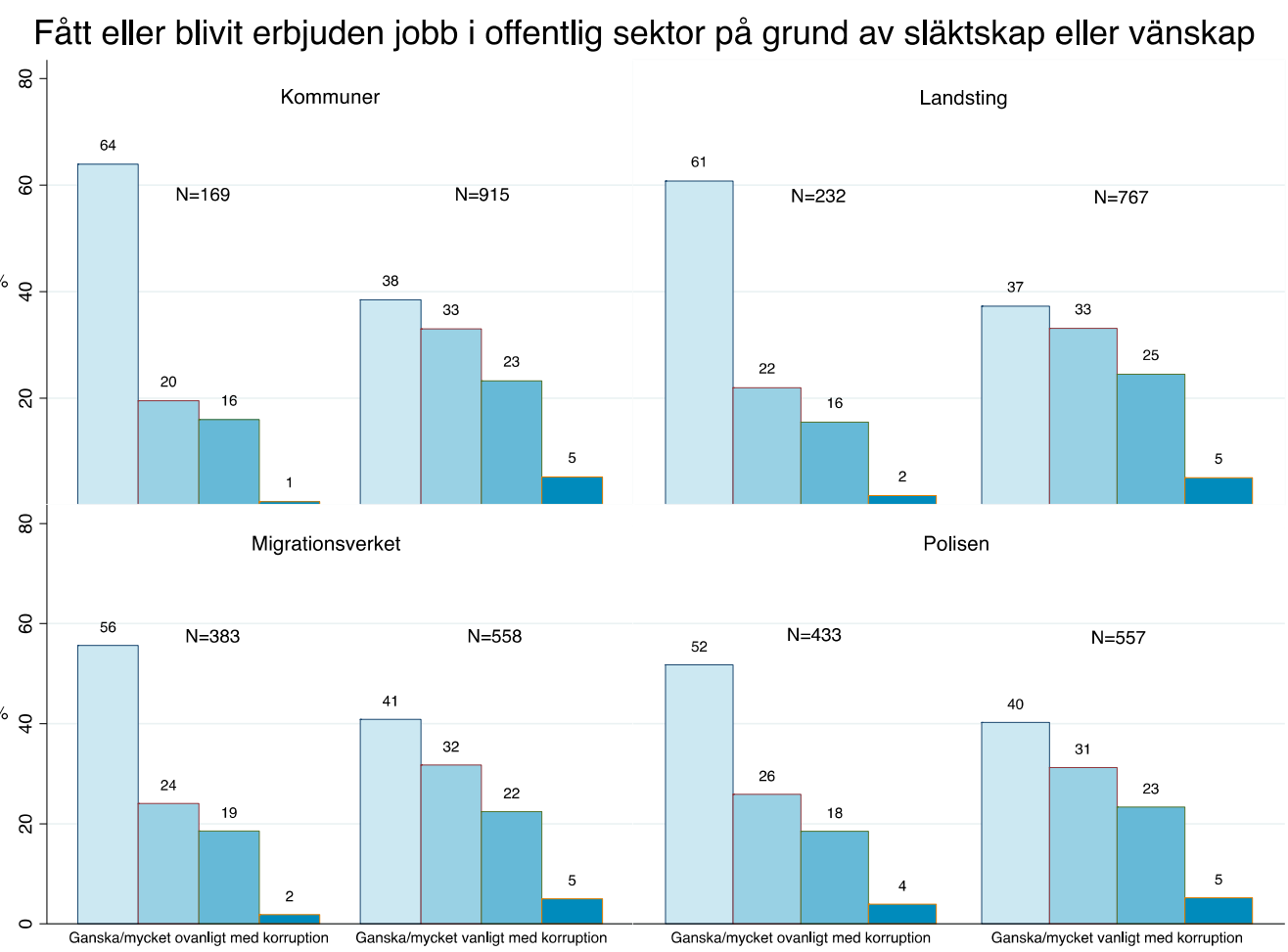


Kommentar: Situationen avser att ha fått eller ha blivit erbjuden jobb i offentlig sektor på grund av släktskap eller vänskap. Se figur 1 och tabell 1 för fullständig information om frågeformulering och svarsalternativ. I var och en av delfigurerna har svarsfördelningen grupperats till vänster för respondenter som ser korruption som (ganska eller mycket) ovanligt, respektive till höger för respondenter som ser korruption som (ganska eller mycket) vanligt. N-talen anger antal svar som kan utnyttjas i respektive analys.

Sammantaget tyder resultaten i figur 2 på att det finns en stark koppling mellan uppfattningar om korruptionens utbredning i den offentliga sektorn och erfarenheter av korruption när vi mäter det med den nepotismliknande situationen (att någon har fått eller har blivit erbjuden jobb i offentlig sektor på grund av släktskap eller vänskap).

Dessutom verkar sambandet mellan att ha erfarenhet av nepotismsituationen och bedömningen av förvaltningen som korrupt vara något starkare för den kommunala nivån (kommuner och landsting) än för staten (Polisen och Migrationsverket), det vill säga skillnaderna mellan de båda gruppernas uppfattningar relaterade till deras erfarenheter av korruption är något större.

Figur 3. Samband mellan erfarenhet av situationen "Presenter" och bedömning av korruption i offentlig förvaltning.

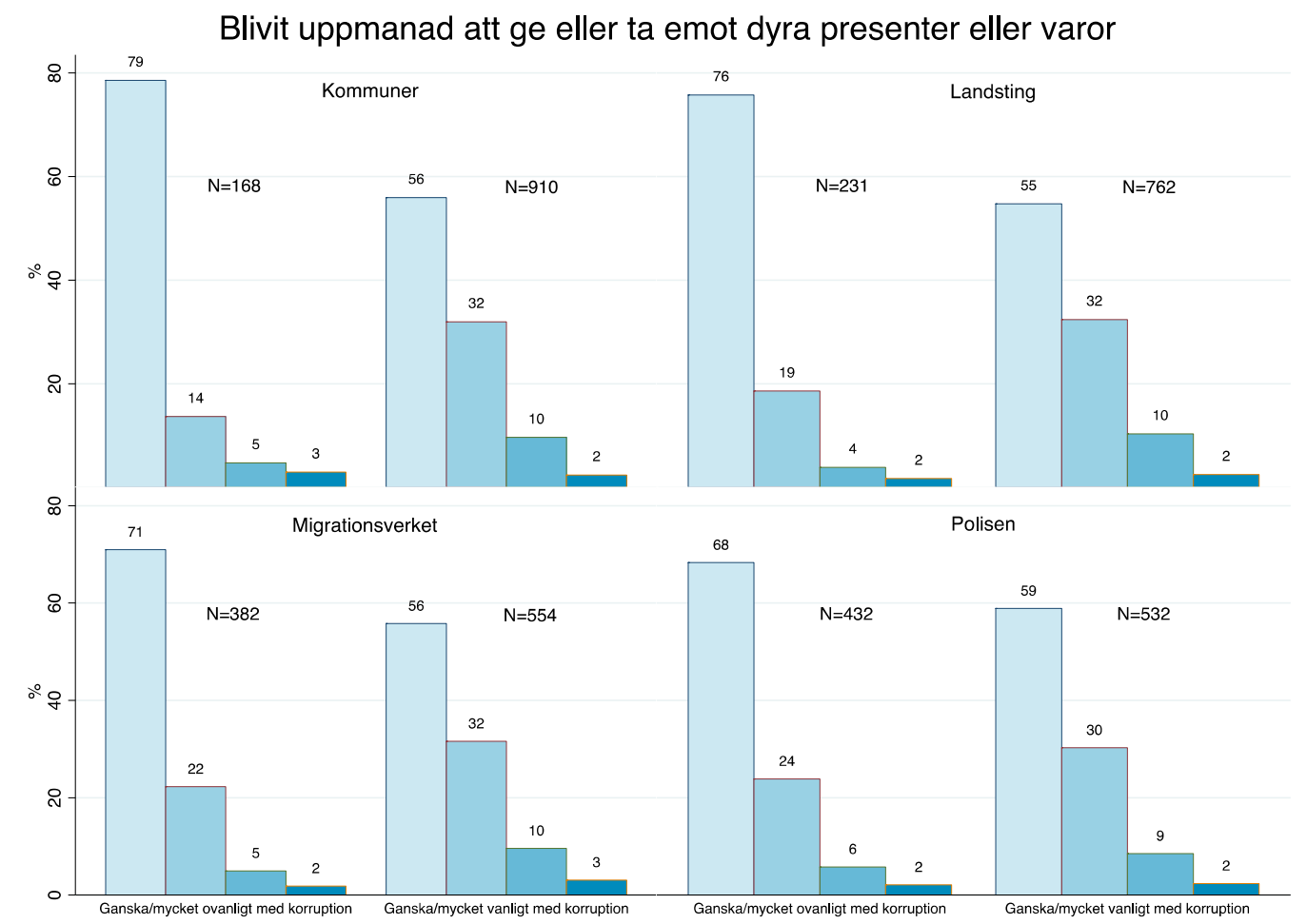
$\mathrm{Nej}$
Ja, jag har hört talas om det, men känner ingen som varit med om detta $\mathrm{Ja}$, jag kănner nágon som varit med om detta
Ja, jag har själv varit med om detta 
Kommentar: Situationen avser att någon i eller i kontakt med offentlig sektor har blivit uppmanad att ge eller att ta emot dyra presenter eller varor. Se figur 1 och tabell 1 för fullständig information om frågeformulering och svarsalternativ. I var och en av delfigurerna har svarsfördelningen grupperats till vänster för respondenter som ser korruption som (ganska eller mycket) ovanligt, respektive till höger för respondenter som ser korruption som (ganska eller mycket) vanligt. N-talen anger antal svar som kan utnyttjas i respektive analys.

Vi övergår nu istället till hur dessa samband mellan erfarenheter av korruption och bedömning av korruption i den offentliga sektorn gestaltar sig när vi gör det för den mutliknande situationen (Presenter), som handlar om att man varit med om att någon i eller i kontakt med offentlig sektor har blivit uppmanad att ge eller att ta emot dyra presenter eller varor (figur 3).

För kommuner är resultatet att av de respondenter som anser att korruptionen är vanlig i kommuner är det ungefär 12 procent som själva varit med om eller känner någon som varit med om situationen. Motsvarande resultat för de som uppfattar korruption som ovanligt förekommande i kommuner är 8 procent. Mönstret för landsting är likartat: av de som anser att korruption är vanlig i landsting var siffran 12 procent mot 6 för de som bedömde korruption som ovanlig. Även när det gäller Migrationsverket och polisen skiljer sig hur många som själva varit med om eller känner någon som varit med om situationen uppdelat på om de bedömt korruption vara vanligt (resultatet är 13 respektive 11 procent) eller ovanligt förekommande i dessa statliga förvaltningar (7 respektive 8 procent). Resultaten visar därmed även för den mutliknande situationen (Presenter) att uppfattningar om korruptionens utbredning och erfarenheter av denna korruptionstyp är relaterade. Däremot ser vi inte det mönster som fanns för nepotismsituationen i figur 2 (Vänskap ger jobb) där skillnaden var tydligare för den kommunala nivån (kommuner och landsting) än den statliga (Migrationsverket och Polisen).

Sammantaget kan vi utifrån resultaten från figur 2 och figur 3 för det första konstatera att respondenter som själva varit med om eller känner någon som varit med om korruptionssituationerna i större utsträckning också bedömer korruption vara vanligt förekommande i förvaltningarna. För det andra är skillnaden mellan de båda gruppernas uppfattningar i relation till deras erfarenheter av korruption något lägre i mutsituationen Presenter än i nepotismsituationen Vänskap ger jobb. För nepotismsituationen framgår också att skillnaden mellan de två grupperna (korruption är vanligt eller ovanligt) hänger tydligare samman med egen erfarenhet av korruption för de kommunala förvaltningarna än de statliga. 


\section{Avslutning: Allmänhetens uppfattning om korruption och dess betydelse}

I artikeln använder vi huvudsakligen data från Survey 2012 för att rikta ljuset mot vilka erfarenheter allmänheten i Sverige har kring olika typer av korruption, hur vanlig man bedömer korruption vara i den offentliga förvaltningens olika nivåer och slutligen hur detta är relaterat det vill säga hur erfarenheter av olika korruptionstyper samvarierar med bedömningar av korruptionens omfattning i den offentliga förvaltningens olika nivåer.

För att studera i vilken utsträckning respondenterna hade erfarenheter av olika typer av korruption användes en fråga om respondenternas erfarenheter kring huruvida politiker eller tjänstemän försöker gynna sig själva otillbörligt i olika sammanhang. Respondenterna fick ta ställning till fyra olika situationer eller scenarion: tre mutliknande situationer och en nepotismliknande situation. Resultatet för de mutliknande situationerna var att en majoritet inte hade någon typ av erfarenhet kring detta även när man räknade in de som svarat att man hört talas om det utan att själv varit med om det eller att känna någon som varit det medan det var en minoritet som inte hade någon erfarenhet av det nepotismliknande scenariot. En viktig skillnad mellan mutsituationerna och nepotismsituationen är att det är fler respondenter som hävdar att de har någon form av egen erfarenhet av nepotismsituationen, antingen genom att man själv varit med om det eller känner någon som varit det. Detta är i linje med vad vi kunde förvänta oss utifrån Johnstons $(2006,2014)$ argument om mutor kontra andra korruptionsformer, där andra korruptionsformers betydelse och frekvens lyfts fram.

Resultaten för hur vanligt förekommande respondenterna uppfattade korruption vara i den offentliga förvaltningens olika nivåer låg i linje med vad vi kunde förvänta oss utifrån tidigare studier: korruption sågs som vanligare på subnationell nivå (i kommuner och landsting) och överstatlig nivå (EU) än på statlig nivå (representerad av Migrationsverket och Polisen).

Utifrån dessa resultat analyserade vi slutligen hur respondenternas bedömningar av korruption i den offentliga förvaltningen (om de bedömde korruption som vanligt eller ovanligt $\mathrm{i}$ förvaltningen och dess olika nivåer) relaterar till deras erfarenheter av olika typer av korruption. Vi gjorde detta dels för den nepotismliknande situationen, att någon har fått eller har blivit erbjuden jobb i offentlig sektor på grund av släktskap eller vänskap, och dels en av mutsituationerna, att någon i eller i kontakt med offentlig sektor har blivit uppmanad att ge eller att ta emot dyra presenter eller varor. Den beskrivande analysen visade på tydliga skillnader i erfarenheter av korruption mellan de som bedömde korruption som vanlig och de som bedömde den som ovanlig. Här är huvudresultatet att respondenter som själva varit med om eller känner någon som varit med om korruptionssituationerna bedömde i större utsträckning korruption som vanligt förekommande i förvaltningarna. Detta resultat gällde i allmänhet oavsett om vi studerar den nepotism- eller mutliknande situationen eller om vi fokuserar på den statliga eller kommunala förvaltningen. 
Dock ska det noteras att vissa skillnader också framgick mellan nepotism- och mutsituationen såsom att skillnaderna i uppfattningar om hur vanlig korruption är mellan de som hade egen erfarenhet av korruption och de som inte hade det var något större vad gäller den förstnämnda situationen. I nepotismsituationen var också skillnaderna mellan de båda gruppernas uppfattningar större för kommuner och landsting än de statliga förvaltningarna medan ett sådant mönster inte förelåg för mutsituationen. Att det framkommer sådana skillnader mellan dessa olika typer av korruption är intressanta i sig och visar på betydelsen av att inkludera olika typer av korruption om vi ska utveckla vår kunskap om korruption, människors erfarenheter och uppfattningar om den. Däremot har vi inte möjlighet att, inom ramen för de data som denna artikel bygger på, avgöra vad dessa skillnader beror på. Det kräver vidare forskning.

Artikeln tog avstamp i litteraturen om korruption och dess utbredning, allmänhetens uppfattningar om korruption och betydelsen av att beakta korruptionens olika former när vi undersöker dessa frågor; inte minst i länder som Sverige, där korruptionen normalt bedöms som låg och där mutor inte förväntas vara särskilt vanligt. Som avslutning konstaterar vi att våra resultat kring allmänhetens erfarenheter av olika typer av korruption och hur dessa erfarenheter hänger ihop med uppfattningar om hur vanlig korruption är på olika nivåer i den offentliga förvaltningen är viktiga. Inte för att de går på tvären mot resultat i tidigare forskning utan snarare därför att de nyanserar och utvecklar dessa. Vi har visat att korruptionsbilden förändras när vi går från att basera den på respondenternas egna erfarenheter till att inkludera vad de hört från andra. Med tanke på hur tidigare forskning pekat på att uppfattningar om korruption påverkar stödet för det demokratiska systemet är ett av de viktigaste resultaten i denna artikel att allmänhetens erfarenheter av korruption i den offentliga sektorn i Sverige och deras bedömning av korruptionens förekomst hänger samman.

\section{Noter}

${ }^{1}$ CPI kom över tid också att bli alltmer ifrågasatt i förhållande till hur det används (se t.ex. Andvig 2005; Arndt \& Oman 2006; Abramo 2007; Andersson \& Heywood 2009; Heywood \& Rose 2014).

${ }^{2}$ För att nämna några: Älvsborgs läns landsting (Andersson 2002); Motala kommun och Göteborgs stad (Wångmar 2013), muthärvan inom Systembolaget (Dagens nyheter 2004-09-27; 2008-04-09), Saabs försäljning av stridsflygplanet Gripen till Sydafrika (Dagens nyheter 201106-16) och byggandet av den nya fotbollsarenan i Solna (Aftonbladet 2012-05-11; 2013-10-29).

${ }^{3}$ Tidigare svenska studier av korruption som använder scenarion visar att respondenterna differentierar mellan olika typer av korruption i termer av hur allvarligt de bedömer dem (se t.ex. Bauhr \& Oscarsson 2011: 91ff ; Bergh m.fl. 2009: 364ff) och på vilken nivå i förvaltningen de är mest förknippade med (se t.ex. Andersson 2002:111ff ).

${ }^{4}$ Detta är således ett erfarenhetsbaserat svarsalternativ som fångar egna erfarenheter. Vi är dock samtidigt fullt medvetna om att ordalydelsen i frågan och de fyra olika situationerna kan 
innebära en vidgning av vad som menas med egen erfarenhet jämfört med om det enbart är begränsat till eget deltagande.

Exempelvis kan svaret att själv varit med om situationen "Presenter” innefatta både att man själv fått en sådan uppmaning som beskrivs eller att man iakttagit hur någon annan fått det. Den ovan nämnda Global Corruption Barometers fråga om mutor, som inte frågar om respondentens erfarenhet utan hushållets, är ett annat exempel på en erfarenhetsbaserad fråga som inte bara omfattar det egna deltagandet (Transparency International 2013). För mer om erfarenhetsbaserade korruptionsmått se t.ex. Teorell 2010 och Heywood \& Rose 2014.

${ }^{5}$ Liknande resultat baserade på den riksrepresentativa enkätundersökningen Survey 2009 redovisas i Andersson 2012: 84.

${ }^{6}$ Typvärden, det vanligast förekommande svaret från respondenterna för respektive institution, tydliggör också detta mönster. Typvärdet för landsting och kommuner är detsamma (Ganska vanligt) vilket förstärker bilden av att respondenterna uppfattar dessa institutioner relativt lika. EU har också detta typvärde. För Polisen och Migrationsverket är svarspersonernas typiska uppfattning att korruption varken är vanligt eller ovanligt.

${ }^{7}$ Resultatet att medborgarna uppfattar korruption som vanligare på EU-nivå än statlig nivå är också i linje med tidigare resultat (se exempelvis Andersson 2002 kapitel 5, där detta bygger på studenters uppfattningar).

${ }^{8}$ Denna uppfattning förstärks också av att resultaten avseende dessa myndigheter var likartade.

${ }^{9}$ Resultaten för de tre mutliknande situationerna var relativt likartade, de är också starkt inbördes korrelerade. De tre mutliknande situationerna är däremot i lägre grad korrelerade med nepotismsituationen (se tabell A2 i Appendix).

${ }^{10} \mathrm{Vi}$ har utöver den redovisade deskriptiva analysen även studerat om medelvärdena skiljer sig åt inom de två grupperna per myndighet. De statistiska testerna (t-test) bekräftar att de redovisade skillnaderna mellan grupperna inom de fyra myndigheterna är statistiskt signifikanta. I tabell A1 i appendix redovisas resultaten från dessa medelvärdestester.

\section{Appendix}

Tabell A1. Medelvärdestest för skillnader i erfarenhet av korruption.

\begin{tabular}{lllc}
\hline & $\begin{array}{l}\text { Fått jobb i offentlig } \\
\text { sektor på grund av } \\
\text { släktskap eller vänskap }\end{array}$ & $\begin{array}{l}\text { Blev uppmanad att ge } \\
\text { eller ta emot dyra } \\
\text { presenter eller varor }\end{array}$ & $N$ \\
\hline Utifrån uppfattad förekomst av & $\begin{array}{l}-0,420^{* * *} \\
(-5,64)\end{array}$ & $\begin{array}{l}-0,264^{* * *} \\
(-4,18)\end{array}$ & 1087 \\
korruption i kommuner & $-0,392^{* * *}$ & $-0,290^{* * *}$ & 1001 \\
\hline Utifrån uppfattad förekomst av & $(-5,91)$ & $(-5,21)$ & 944 \\
korruption i landsting & $-0,250^{* * *}$ & $-0,222^{* * *}$ & \\
\hline Utifrån uppfattad förekomst av & $(-4,27)$ & $-4,52)$ & 992 \\
korruption inom Migrationsverket & $-0,189^{* *}$ & $-0,127^{* *}$ & \\
\hline Utifrån uppfattad förekomst av & $(-3,26)$ & & \\
korruption inom Polisen & & & \\
\hline
\end{tabular}


Kommentar: Tabellen redovisar skillnader i medelvärden med avseende på erfarenheter av korruption (jfr figur 1 ovan) mellan de som uppfattar korruption som (mycket eller ganska) vanlig och de som uppfattar korruption som (mycket eller ganska) ovanlig (jfr tabell 1 ovan) för respektive preciserad del av den offentliga förvaltningen. Statistisk signifikans: ${ }^{* *} p<0,001{ }^{* *} p<0,01{ }^{*} p<0,05$ ( $t$-värden har angetts inom parentes).

\section{Tabell A2. Samband mellan de beskrivna korruptionssituationerna}

\begin{tabular}{|c|c|c|c|c|}
\hline & $\mathrm{A}$ & $\mathrm{B}$ & $\mathrm{C}$ & $\mathrm{D}$ \\
\hline A. Erbjuden/uppmanats att erbjuda pengar & 1 & & & \\
\hline $\begin{array}{l}\text { B. Fått jobb i offentlig sektor på grund av släktskap } \\
\text { eller vänskap }\end{array}$ & $\begin{array}{l}0.326^{* * *} \\
(1501)\end{array}$ & 1 & & \\
\hline $\begin{array}{l}\text { C. Blev uppmanad att ge eller ta emot dyra presenter } \\
\text { eller varor }\end{array}$ & $\begin{array}{l}0.499^{* * *} \\
(1496)\end{array}$ & $\begin{array}{l}0.351^{* * *} \\
(1497)\end{array}$ & 1 & \\
\hline $\begin{array}{l}\text { D. Uppmanats att bjuda på eller har fått erbjudande om } \\
\text { dyr resa som gåva }\end{array}$ & $\begin{array}{l}0.492^{* * *} \\
(1498)\end{array}$ & $\begin{array}{l}0.387^{* * *} \\
(1500)\end{array}$ & $\begin{array}{l}0.610^{* * *} \\
(1497)\end{array}$ & 1 \\
\hline
\end{tabular}

Statistisk signifikans: ${ }^{* * *} p<0,001{ }^{* *} p<0,01{ }^{*} p<0,05$ ( $N$-talen har angetts inom parentes).

\section{Referenser}

Abramo, Claudio Weber (2007): How Much Do Perceptions of Corruption Really Tell Us?

Economics Discussion Papers 2007-19, http://www.economics-ejournal.org/economics/discussionpapers/2007-19 (hämtad 2007-1020).

Aftonbladet 2012-05-11: Villkorligt i mål om arenamutor.

http://www.aftonbladet.se/nyheter/article14813541.ab (hämtad 2015-01-25).

Aftonbladet 2013-10-29: Hovrättsdom om mutor vid arenabygge.

http://www.aftonbladet.se/nyheter/article17745689.ab (hämtad 2015-01-25).

Alam, M. Shahid (1995): “A theory of limits on corruption and some applications”, Kyklos 48:3, 419-435.

Andersson, Staffan (2002): Corruption in Sweden: Exploring Danger Zones and Change (PhD thesis), Department of Political Science, Umeå University.

Andersson, Staffan (2012): ”Antikorruption: arbetet mot korruption”, s. 99-112 i Andersson, Staffan, ed., Motståndskraft, oberoende, integritet: Kan det svenska samhället stå emot korruption?, Stockholm: Transparency International Sverige.

Andersson, Staffan \& Gissur Ó Erlingsson (2010): ”Förvaltningsreformer och korruptionsrisker” s. 192-234 i Andersson, Staffan, Andreas Bergh, Gissur Ó. Erlingsson \& Mats Sjölin, red., Korruption, maktmissbruk och legitimitet, Stockholm: Norstedts. 
Andersson, Staffan \& Paul M. Heywood (2009): "The Politics of Perception: Use and Abuse of Transparency International's Approach to Measuring Corruption", Political Studies 57: 746767.

Andersson, Staffan \& Frank Anechiarico (2015): “The political economy of conflicts of interest in an era of public private governance”, i Heywood, Paul M. (red.) The Routledge International Handbook of Political Corruption, Abingdon: Routledge.

Andvig, Jens C. (2005): ”“A house of straw, sticks or bricks’? Some notes on corruption empirics” Nupi paper 678, Norwegian Institute of International Affairs.

Andvig, Jens C. \& Karl Ove Moene (1990): How corruption may corrupt, University of Oslo, Department of Economics, reprint series.

Arndt, Christiane \& Charles Oman (2006): Uses and Abuses of Governance Indicators. Paris: Development Centre of the OECD.

Bauhr, Monika \& Henrik Oscarsson, (2011): ”Svenska folkets syn på korruption”, 85-95 i Holmberg, Sören, Weibull, Lennart \& Henrik Oscarsson (red.) Lycksalighetens ö. Göteborg: SOM-institutet, Göteborgs universitet.

Bergh, Andreas, Erlingsson Gissur \& Mats Sjölin (2009): ’Egoism, grupplojalitet och korruption i svensk kommunalpolitik: Lärdomar från spelteori och experimentell samhällsvetenskap”. Statsvetenskaplig Tidsskrift 111 (4): 347-373

Bergh, Andreas, Erlingsson Gissur, Sjölin Mats \& Richard Öhrvall (2013): Allmän nytta eller egen vinning? - en ESO-rapport om korruption på svenska. Rapport till expertgruppen för studier i offentlig ekonomi 2013:2. Stockholm: RegeringskansliCars, Thorsten (2012): Mutbrott och korruptiv marknadsföring. Stockholm: Norstedts Juridik

Charron, Nicholas, Victor Lapuente \& Bo Rothstein (2011): Korruption i Europa. En analys av samhällsstyrningens kvalitet på nationell och regional nivå i EU:s medlemsstater, Sieps rapport 2011:5.

Charron, Nicholas, Victor Lapuente \& Bo Rothstein (2013): Quality of government and corruption from a European perspective: a comparative study of good goverment in EU regions, Northampton: Edward Elgar.

Dagens Nyheter 2004-09-27: Detta har hänt i muthärvan. www.dn.se/nyheter/sverige/detta-har-hant-i-mutharvan (hämtad 2015-01-25)

Dagens Nyheter 2008-04-09: Systemchefer fällda i tingsrätten. http://www.dn.se/nyheter/sverige/systemchefer-fallda-i-tingsratten (hämtad 2015-01-25)

Dagens Nyheter 2011-06-16: Saab medger mutor till Sydafrika. http://www.dn.se/ekonomi/saabmedger-mutor-till-sydafrika (hämtad 2015-01-26)

De Sousa, Luis, Peter Larmour \& Barry Hindess (2009): "Introduction” i Governments, NGOs and Anti-corruption: The new integrity Warriors. Abingdon Oxon: Routledge 
Erlingsson, Gissur Ó (2006): ”Organisationsförändringar och ökad kommunal korruption”, Kommunal ekonomi och politik, Volym 3, nr. 1, 7-40.

Erlingsson, Gissur Ó (2010): ”Ska vi oroa oss för korruption och maktmissbruk i Sverige?”, i Hagevi, Magnus, red., Ny politik i ett gammalt samhälle. Växjö: Linnaeus University Press

Erlingsson, Gissur O. \& Andreas Bergh (2008): "Public Corruption in Swedish Municipalities: Trouble Looming on the Horizon?, Local Government Studies 34 (5): 595-608.

Erlingsson, Gissur Ó \& Jonas Linde (2011a). ”Det svenska korruptionsproblemet”, Ekonomisk Debatt 39 (8): 5-18.

Erlingsson, Gissur Ó \& Jonas Linde (2011b): ”Korruption i Sverige”, s 137 - 152 i Hellberg, Ann-Sofie, Martin Karlsson, Hannu Larsson, Erik Lundberg och Monika Persson, red. Perspektiv på offentlig verksamhet i utveckling: Tolv kapitel om demokrati, styrning och effektivitet, Örebro: Örebro universitet.

European Commission (2014): EU anti-corruption report, Report from the Commission to the Council and the European Parliament.

http://ec.europa.eu/dgs/home-affairs/what-we-do/policies/organized-crime-and-humantrafficking/corruption/anti-corruption-report/index_en.htm (hämtad 2014-03-15).

Hagevi, Magnus (2014): ”Survey 2012: Teknisk rapport”, Surveyjournalen 1(1):59-67.

Heidenheimer, Arnold J. (1989): "Perspectives on the Perception of Corruption”, pp. 149-163 in Heidenheimer, Arnold J., Johnston, Michael and LeVine, Victor (eds) Political Corruption: A Handbook, NewBrunswick: Transaction publishers.

Heywood, Paul (1997): "Political Corruption: Problems and Perspectives”, Political Studies, 45 (3): 417-435.

Heywood, Paul M. \& Jonathan Rose (2014): "“'Close but no Cigar”: the measurement of corruption", Journal of Public Policy 34, (3): 507-529.

Heywood, Paul M. (2015):”Introduction: scale and focus in the study of corruption”, i Heywood, Paul M., ed. Routledge Handbook of political corruption. Milton Park, Abingdon Oxon: Routledge.

Johnston, Michael (2005): Syndromes of Corruption: Wealth, Power, and Democracy. Cambridge: Cambridge University Press.

Johnston, Michael (2006): Assessing the Progress of Anti-Corruption Efforts: "Actionable" Indicators of Reform, manuscript, Colgate University 2006.

Johnston, Michael (2014): Corruption, contention and reform: the power of deep democratization, New York: Cambridge University Press.

Krastev, Ivan (2003): “When "should” does not imply “can”: the making of the Washington consensus on corruption', www.colbud.hu/honesty-trust/krastev/pub01.PDF (hämtad_2013-09- 
30) (Se också 2004. Shifting Obsessions: Three Essays on the Politics of Anticorruption, Central European University Press)

Kurtz, Marcus J \& Andrew Schrank (2007): "Growth and governance: Models, measures, and mechanisms", Journal of politics, vol.69 (2):538-554.

Linde, Jonas \& Gissur Ó Erlingsson (2013): “The Eroding Effect of Corruption on System Support in Sweden”. Governance, 26: 585-603 (Early view online).

Marquette, Heather (2004): "The creeping politicisation of the World Bank: the case of corruption”, Political Studies 52: 413-430.

OECD (2011): Convention on combating bribery of foreign public officials in international business transactions and related documents.

http://www.oecd.org/daf/anti-bribery/ConvCombatBribery_ENG.pdf (hämtad 2015-01-20)

Oscarsson, Henrik (2010):”Mutor och korruption”, i Holmberg, Sören \& Lennart Weibull, red., Nordiskt ljus. Trettiosju kapitel om politik, medier och samhälle. SOM-rapport nr. 50.

Göteborgs universitet.

Philip, Mark (2015): The definition of political corruption”, i Heywood Paul M. Ed. Routledge Handbook of political corruption. Milton Park, Abingdon Oxon: Routledge.

Rothstein, Bo \& Jan Teorell (2008): "What is Quality of Government? A Theory of Impartial Government Institutions.” Governance 21 (2): 165-190.

Hols Salén \& Lars Korsell (2013): Den anmälda korruptionen i Sverige: struktur riskfaktorer och motåtgärder, Brottsförebyggande rådet (BRÅ).

Statskontoret (2012): Köpta relationer: om korruption i det kommunala Sverige, 2012:20, Stockholm: Statskontoret.

Svenska Dagbladet 2013-03-25: Muthärva på migrationsverket växer. www.svd.se/nyheter/inrikes/mutharva-pa-migrationsverket-vaxer_8028088.svd (hämtad 201501-27).

Sydsvenskan 2013-06-25: Härvan kring migrationsverket sväller.

www.sydsvenskan.se/sverige/harvan-kring-migrationsverket-svaller (hämtad 2015-01-27).

Teorell, Jan (2010): ”Att mäta korruption”, i Andersson, Staffan, Andreas Berg, Gissur Ó Erlingsson \& Mats Sjölin, red. (2010), Korruption, maktmissbruk och legitimitet, Stockholm: Nordstedts Förlag.

Transparency International (2006): Report on the Transparency International Global Corruption Barometer 2006.

Transparency International (2007): Report on the Transparency International Global Corruption Barometer 2007.

Transparency International (2013).Global Corruption Barometer 2013. 
Transparency International (2014): Corruption Perceptions Index, http://www.transparency.org/cpi2014 (hämtad 2015-01-19).

Wolfowitz, Paul (2006): Good Governance and Development-A Time For Action, tal i Jakarta 2006-11-04, http://www.cfr.org/international-organizations-and-alliances/world-bankcorruption/p10504 (hämtad 2015-01-20).

Worldwide Governance Indicators (2012): Officiell webbplats (2012), > WGI Data Sources, htp://info.worldbank.org/governance/wgi/resources.htm (hämtad: 2012-12-04).

Wångmar, Erik (2013): Tillit och korruption: korruption, maktmissbruk och bristande tillit i svensk lokalpolitik 1963-2011, Stockholm: Santérus. 